\title{
Impacts of Treated Wastewater on the Surface Water and Groundwater Quality: A Case Study in North East Gaborone, Botswana
}

\author{
Tshepo $\mathrm{K}^{1}$ \\ Tafesse NT $^{2}$ (iD \\ Chaoka RT ${ }^{3}$ (D) \\ Alemaw BF ${ }^{4}$ \\ Laletsang $\mathrm{K}^{5}$
}

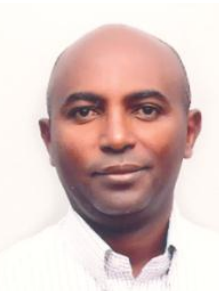

( Corresponding Author)

\begin{abstract}
This study was conducted in the Notwane catchment where the capital city of Botswana, Gaborone is located. Botswana having unreliable rainfalls and Gaborone having shortage supply of water for drinking, this study was initiated with the aim of investigating alternative sources in this part of the country. Even though treated wastewater is available in the studied area, this water is not much utilized at present. The objective of the research is to investigate the impact of treated wastewater on the quality of surface water and groundwater in the north east of Gaborone, so that this water can be utilized for different purposes including as a source for groundwater recharge. The research area is located near Gaborone in south east district within Notwane catchment, which is a tributary to the Limpopo River, having an area of about 3000 sq. $\mathrm{kms}$. For this purpose forty-one surface water samples, one treated wastewater sample and fifteen groundwater samples were collected from different parts of the study area. All the water samples were analysed for major cations $\left(\mathrm{Ca}^{2+}, \mathrm{Mg}^{2+}, \mathrm{K}^{+}, \mathrm{Na}^{+}\right.$and $\left.\mathrm{Li}^{+}\right)$, anions $\left(\mathrm{HCO}_{3}^{-}, \mathrm{Cl}^{-}, \mathrm{SO}_{4}{ }^{2-}, \mathrm{NO}_{3}{ }^{-}, \mathrm{F}-\right.$, $\mathrm{PO}_{4}{ }^{3-}$ and $\mathrm{CO}_{3^{2-}}$ ) and some trace elements (As, $\mathrm{Ba}, \mathrm{Cd}, \mathrm{Co}, \mathrm{Cr}, \mathrm{Cu}, \mathrm{Fe}, \mathrm{Mn}, \mathrm{Pb}, \mathrm{Ni}$ and $\mathrm{Zn}$ ). For all the water samples alkalinity and hardness were determined using AquaChem software. Simple descriptive statistical method was utilized for the analyses of the water chemistry data. AquaChem and Suffer software's were also used for analyses the water chemistry data. The surface water range from slightly alkaline to very hard whereas the treated wastewater is slightly alkaline to hard and groundwater is slightly acidic to very hard.In all the waters, surface water, treated wastewater and groundwater based on the mean values of the chemical parameters, the cations were in the order of abundance as $\mathrm{Na}^{+}>\mathrm{Ca}^{2+}>\mathrm{Mg}^{2+}>\mathrm{K}^{+}>\mathrm{Li}^{+}$. Surface water anions were in the order of abundance as $\mathrm{HCO}_{3}{ }^{-}>\mathrm{Cl}^{-}>\mathrm{SO}_{4}{ }^{2-}>\mathrm{NO}_{3}{ }^{-}>\mathrm{PO}_{4}{ }^{3-}>\mathrm{F}^{-}>\mathrm{CO}_{3}{ }^{2-}$, treated wastewater as $\mathrm{HCO}_{3}{ }^{-}>\mathrm{Cl}^{-}>\mathrm{NO}_{3}{ }^{-}>\mathrm{SO}_{4}{ }^{2-}>\mathrm{PO}_{4}{ }^{3-}>\mathrm{F}^{-}>\mathrm{CO}_{3}{ }^{2-}$ while in the groundwater the anions reveal order of abundance as $\mathrm{Cl}^{-}>\mathrm{HCO}_{3}{ }^{-}>\mathrm{SO}_{4}{ }^{2-}>\mathrm{NO}_{3}{ }^{-}>\mathrm{CO}_{3}{ }^{2-}>\mathrm{F}^{-}>\mathrm{PO}_{4}{ }^{3-}$. Based on the mean values of the chemical parameters in the surface water, the analyzed trace elements were in the order of abundance as $\mathrm{Ni}>\mathrm{Fe}>\mathrm{Pb}>\mathrm{Ba}>\mathrm{Zn}>\mathrm{Mn}>\mathrm{Cd}>\mathrm{As}>\mathrm{Co}>\mathrm{Cr}>\mathrm{Cu}$, in the treated water $\mathrm{Ni}>$ $\mathrm{Ba}>\mathrm{Zn}>\mathrm{Pb}>\mathrm{Fe}>\mathrm{Cd}>\mathrm{Mn}>\mathrm{As}>\mathrm{Co}>\mathrm{Cr}$ and $\mathrm{Cu}$ having equal concentration (o mg/l) while in the groundwater the analyzed trace element reveal order of abundance as $\mathrm{Ni}>\mathrm{Pb}>\mathrm{Ba}>\mathrm{Mn}>$ $\mathrm{Zn}>\mathrm{Fe}>\mathrm{Cd}>\mathrm{As}>\mathrm{Cu}>\mathrm{Co}>\mathrm{Cr}$. The results of the hydrochemical analyses of all the waters disclose that the groundwater chemistry is highly controlled by rock-water interaction and anthropogenic activities in the catchment than the chemistry of surface water and treated wastewater. The analysed cations for surface water and treated wastewater satisfy the standard of both WHO and Botswana Bureau of Standards whereas in the groundwater the cations are highly above the recommended limits of the standards set by both WHO and Botswana Bureau of Standards with the exception of lithium and potassium. The analysed anions for surface water and treated wastewater fulfil the standard of both WHO and Botswana Bureau of Standards whereas in the groundwater the concentration of $\mathrm{Cl}$ and $\mathrm{NO}_{3}$ were above the standards set by both WHO and Botswana Bureau of Standards. In the analysed trace elements for all the waters, almost all samples met the trace element standards set by both WHO and Botswana Bureau of Standards with the exception of nickel and lead in surface water, treated wastewater and groundwater. The overall chemical analyses of the water chemistry revealed that treated wastewater quality does not have any significant harm to both surface and groundwater quality; therefore it can be used as a source of recharge to the aquifers in the catchment.
\end{abstract}


Citation | Tshepo K; Tafesse NT; Chaoka RT; Alemaw BF; Laletsang K (2017). Impacts of Treated Wastewater on the Surface Water and Groundwater Quality: A Case Study in North East Asian Review of Environmental and Earth Sciences, 4(1): 36-45.

History:

Received: 4 October 2017

Revised: 6 December 2017

Accepted: 11 December 2017

Published: 14 December 2017

Licensed: This work is licensed under a Creative Commons Attribution 3.0 License (c) (BY

Publisher:Asian Online Journal Publishing Group
Contribution/Acknowledgement: All authors contributed to the conception and design of the study.

Funding: The financial support from ORD office of the University of Botswana and the Department of Geology are highly acknowledged.

Competing Interests: The authors declare that they have no conflict of interests.

Transparency: The authors confirm that the manuscript is an honest, accurate, and transparent account of the study was reported; that no vital features of the study have been omitted; and that any discrepancies from the study as planned have been explained.

Ethical: This study follows all ethical practices during writing.

\section{Contents}

1. Introduction

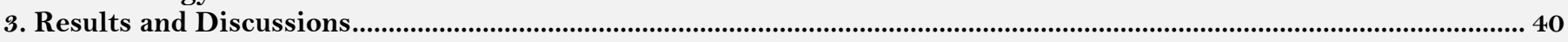

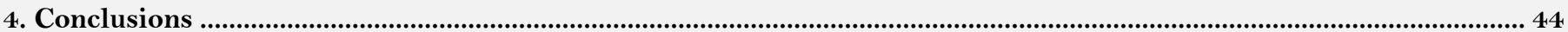

\section{Introduction}

\subsection{General}

Sewage water refers to the water that has biological, physical and chemical contaminants which is generated by resident, institutional and commercial industrial establishment. Water is said to be polluted when it contains enough impurities to make it unfit for a particular use, such as drinking, swimming, or fishing. Sewage water treatment refers to the process of reducing the contaminants to acceptable levels to make the water safe for discharge back into the environment and reuse for irrigation, washing, construction and many more. It includes the physical, biological and chemical processes to remove physical chemical and biological contaminants. The general sewage (wastewater) treatment involves four stages, screening, primary, secondary and tertiary treatment.

Water quality standards are designed to provide us with understanding the critical importance of adequate supplies of clean, available fresh water for the environment, the country's economy and the quality of life. Botswana Bureau of Standards (BOBS) has established upper limits and ranges for chemical levels allowable in drinking, irrigation and livestock water. Most of these levels allow a sufficient margin of safety. It must be noted that acceptable contaminant levels vary widely among individuals, for example high sodium which may be harmless for many people can be dangerous for elderly, hypertensive persons, pregnant women and people having difficulty in excreting sodium.

Botswana is experiencing shortage of water supply due to prolonged dry seasons and declined rainfall amounts.In support of that the annual has decreased and it was found out that rainfall quantiles with a 10-year recurrence interval will decrease by 2-17\% [1]. According to Botswana Central Statistics Office [2] water from dams and rivers contribute about one third to national water consumption. An increasingly large proportion of the population which resides in the urban areas as a result of urban migration is supplied by water from the dams. Gaborone dam supplies water to two towns: Gaborone and Lobatse. The dam is located along Notwane River and has a storage capacity of 141.1 million cubic meters. Its water is supplemented by Bokaa dam located along the Metsimotlhabe River in Kgatleng District.

According Botswana Central Statistics Office [2] the population of Gaborone has increased from 186 o07 in year 2001 to 231592 in 2011 and forecasted an increase to 259300 in 2016 which directly also indicate an increment in the water demand. Statistics also indicated that Gaborone uses about 2 824 $291^{*} 10^{3}$ litter of water monthly. The high water demand in southern parts of Botswana prompted the operation of North South Carrier (NSC) pipeline that supplies water from Dikgathong Dam in the Northern part of Botswana, to Gaborone and surroundings in the southern part of the country. Furthermore Botswana Bureau of Standards [3] revealed that there was high reliance on the North South Carrier (NSC) that seemed to operate at maximum capacity. Water transferred through the NSC between 2012/13 and 2013/14 has increased and amounts to 23.6 and 36.1 million cubic meter, respectively, in the given period and that has brought water conservation strategies and reuse into consideration.

Treated wastewater became an alternative and reduced the reliance on fresh water for purposes such as irrigation and construction. In the study area the wastewater treatment plant is located on latitude $24.61^{\circ} \mathrm{S}$ and longitude $25.96^{\circ} \mathrm{E}$ in Glen Valley (Gaborone North-east), downstream of Gaborone Dam. The first phase of a treatment works has a capacity of $40,000 \mathrm{~m}^{3} /$ day and operating at an average of $20000 \mathrm{~m}^{3} /$ day. The second face of the plant has a capacity of $50000 \mathrm{~m}^{3} /$ day and has not started operating which totals to $90000 \mathrm{~m}^{3} / \mathrm{day}$ if the plant operates at $100 \%$. The treatment plant is expected to treat all the wastewater generated in the greater Gaborone and it also has an emergency overflow sewage-retaining dam. After treatment the water is pumped to maturation ponds, the ponds allow the water for further treatment as the water stays there for 15 days before it can be discharged into Game Park. The water from the maturation converges at the pump station where it pumped to existing reservoirs where it is utilised for various purposes such as irrigation and construction. The water in the ponds is also a source of aquatic life, birds, other animals and beautiful reeds. Furthermore, the area near the ponds slopes to the Notwane River, which is the main stream in the catchment. Water resources of the study area are dominated by the Notwane River that flow downstream of Gaborone dam and treated wastewater from wastewater treatment plant, which also flows to the Notwane river.

The impacts of treated wastewater in Gaborone are generally based on wastewater movement on the surface and underground. The greatest threats posed to water resources arise from contamination by bacteria, nitrates, metals, trace quantities of toxic material and salts. Seepage overflow into drinking water sources can cause diseases from ingestion of micro-organisms and heavy metals. According to Emongor and Ramolemana [4] there are physical and chemical soil related problems associated with using secondary treated sewage water in horticultural 
production. The physical problems include clogging, soil drainage and aeration while the chemical problems include soil salinity, sodicity and accumulation of heavy metals. Groundwater contamination is a concern in Botswana two well fields, the Ramotswa and the Mochudi well fields, which are located in the south-eastern part of Botswana. The well fields are no longer used for water supply sources for drinking purposes as a result of bacterial and nitrate pollutions caused by poor disposal sanitary waste [5]. As abstraction rates increases in the wells of these well fields, the cone of depression increases and water would be drawn from far and often interferes with many pollutions sources.

\subsection{Objectives}

The major objective of this research was to investigate the impact of treated wastewater on the quality of surface water and groundwater in the North-east of Gaborone.

The following were the specific objectives the research.

- To investigate the major ions and trace element composition of the surface water:

- To investigate the major ions and trace element composition of the groundwater:

- To investigate the major ions and trace element composition of the treated wastewater:

- To investigate the impact of the treated wastewater on the groundwater quality:

- To investigate the suitability of the treated wastewater for drinking purpose: and,

- To investigate the suitability of the treated wastewater as a recharge source for the aquifers in the Gaborone area.

\subsection{Description of the Study Area}

The research area is located near Gaborone in south east district bounded between $23.7^{\circ} \mathrm{S}$ and $24.7^{\circ} \mathrm{S}$ and $25.8^{\circ} \mathrm{E}$ and $27.0^{\circ} \mathrm{E}$ within Notwane catchment which has a total area of about 18053 square kilometres. It is bound to the southwest by the Southern District, to the northwest by the Kweneng District and in the north by the Kgatleng District. The entire eastern part of the district borders with South Africa. Hydrologically, the study area is along the Notwane River downstream of the Gaborone dam about 3000 square kilometres to Mmakgopong village. The Notwane River is a tributary of Limpopo River.In general the area is undulating with slopes from south-east (upstream) to north-east (downstream). The Notwane River drains north - east into the Limpopo River and has tributaries Metsimotlhaba, Thagale and Monametsanarivers. The climate of the study area is generally semi-arid with an annual average rainfall varying between $250-500 \mathrm{~mm}$, unreliable, unevenly distributed and highly variable from year to year and together with a very high amount of evaporation which is of the order of about $2000 \mathrm{~mm} / \mathrm{annum}$. The study is area occupied with the city of Gaborone, Oodi, Morwa, Malotwane, Mmakgopong villages and other small settlements. There are several economic activities in and around the city leading to major and small-scale industrial, commercial and institutional developments

Figure 1 and 2 shows the location of the study area, which start from the South east (Gaborone city) district into Kgatleng district and the study area boundary in Notwane Catchment.

\section{LOCATION MAP}

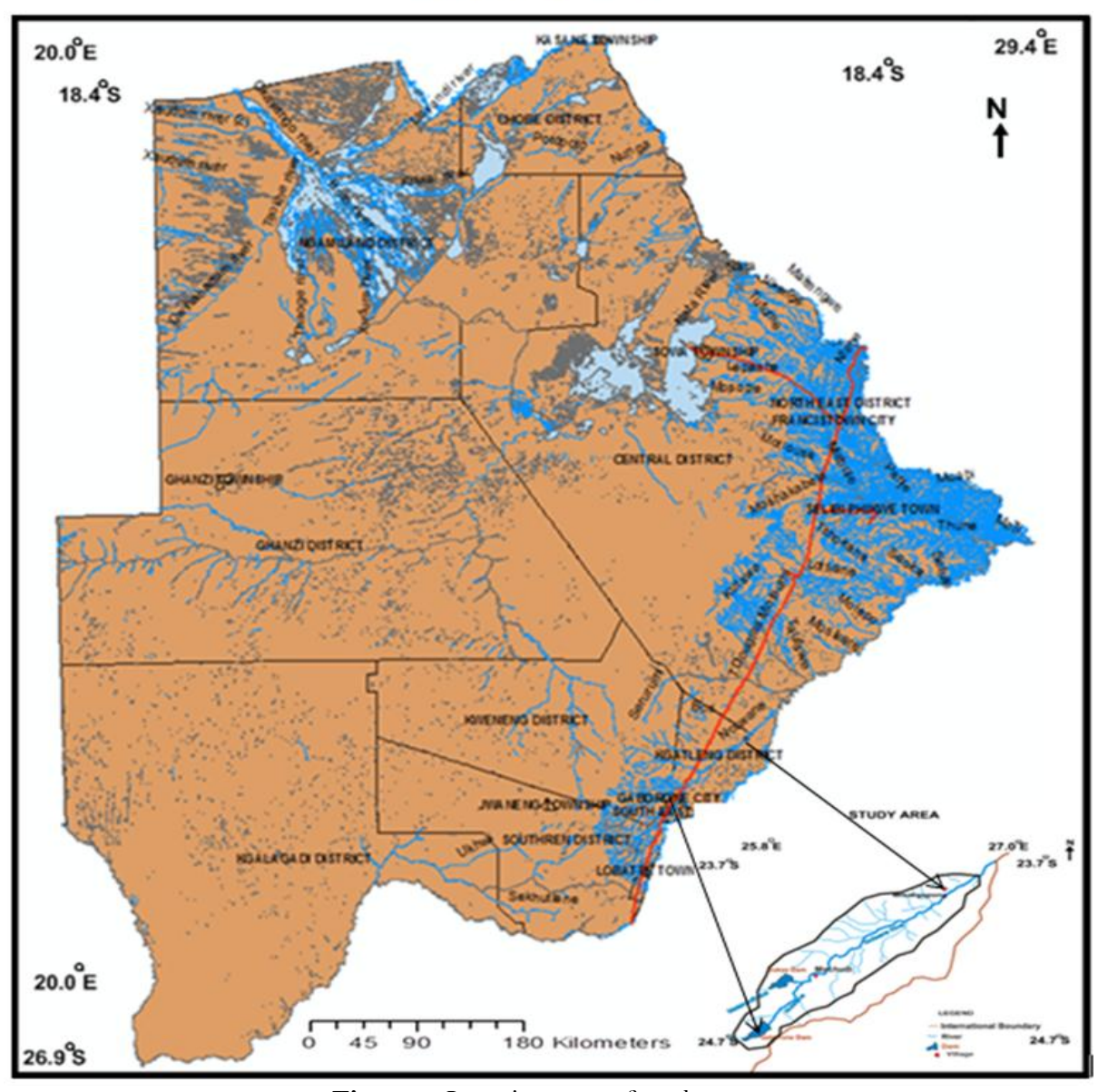

Figure-1.Location map of study area.

Source: Tshepo K., M.Sc. Thesis, University of Botswana, Gaborone, Botswana, 2017. 


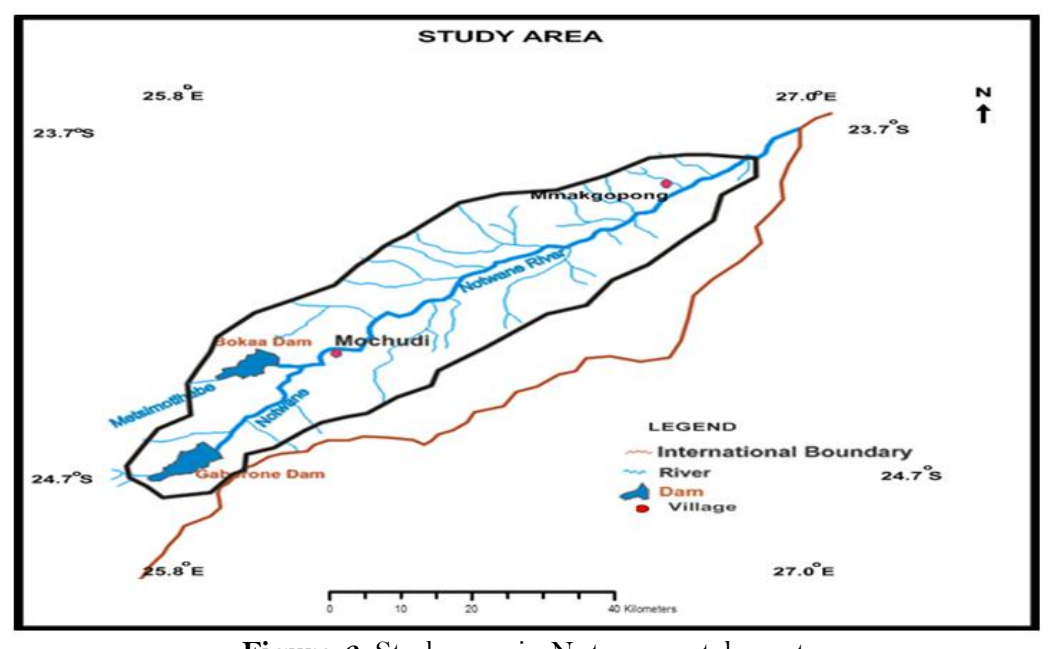

Figure-2. Study area in Notwane catchment.

Source: Tshepo K., M.Sc. Thesis, University of Botswana, Gaborone, Botswana, 2017.

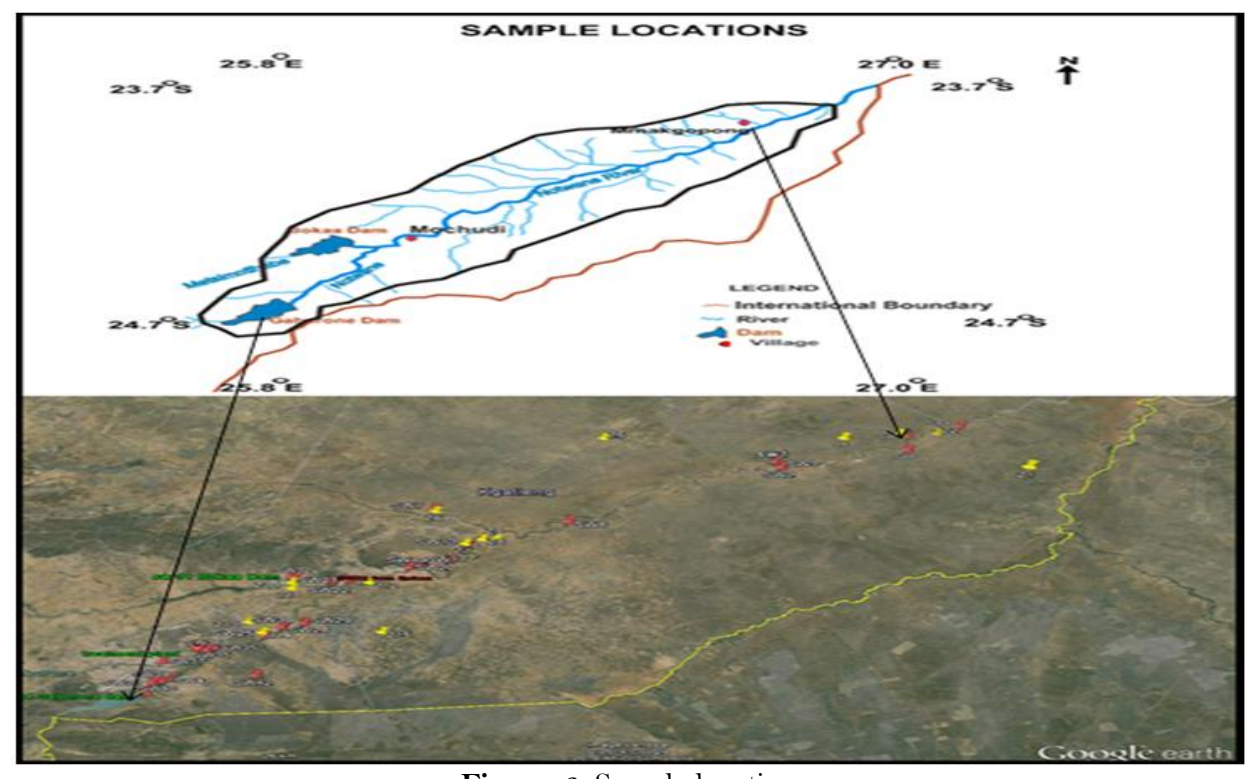

Figure-3. Sample location

Source: Tshepo K., M.Sc. Thesis, University of Botswana, Gaborone, Botswana, 2017.

\section{Methodology}

\subsection{General}

In order to achieve the mentioned objective of the research primary and secondary data were collected at different times of the research period. Primary data were collected both in the field and in the laboratory using different techniques. Secondary data such as location of boreholes, geological reports and maps, rainfall records, soils and land use were collected from different office in Gaborone.

Surface water and groundwater samples were collected from February to April in 2016 from different parts of the study area (Figures 3). Physico-chemical parameters such as pH, total dissolved solids (TDS), electrical conductivity (EC) and temperature were measured for all the samples using portable digital multi parameter analyser in situ immediately after sampling. All the samples were analysed for major cations, anions trace elements.

\subsection{Data Collection}

Forty-one surface water samples were collected starting from the Gaborone dam downstream along the river to the catchment common outlet at Mmakgopong village: twenty six surface water samples were collected at different location from Notwane River starting from the upstream side of the study area (after the Gaborone dam) to the outlet (Figure 3), nine surface water samples were also collected from the tributaries of the Notwane River before their respective junction point and six samples were collected from dams and small ponds inside the study area. Surface water sampling was done following the flow direction of the surface waters. One sample was collected from the pond that is located at mouth of the last treatment plant as a representative to the treated wastewater. Fifteen groundwater samples were collected from the boreholes that are found in the area close to the Notwane River and far away from the influence of the river (Figure 3).

The water samples were collected in one litre Polyethylene terephthalate bottles. Prior to sampling the bottles were rinsed with samples to be collected. All the sampling points were located with the help of GPS.

\subsection{Data Analysis}

The water samples were analysed for major cations $\left(\mathrm{Ca}^{2+}, \mathrm{Mg}^{2+}, \mathrm{K}^{+}, \mathrm{Na}^{+}\right.$and $\left.\mathrm{Li}^{+}\right)$, anions $\left(\mathrm{HCO}_{3}^{-}, \mathrm{Cl}^{-}, \mathrm{SO}_{4}{ }^{2-}\right.$, $\mathrm{NO}_{3}{ }^{-}, \mathrm{F}^{-}, \mathrm{PO}_{4}{ }^{3-}$ and $\mathrm{CO}_{3}{ }^{2-}$ ) and trace elements. The trace elements that were analysed were arsenic (As), barium $(\mathrm{Ba})$, cadmium $(\mathrm{Cd})$, Cobalt $(\mathrm{Co})$, chromium $(\mathrm{Cr})$, copper $(\mathrm{Cu})$, iron $(\mathrm{Fe})$, manganese $(\mathrm{Mn})$, lead $(\mathrm{Pb})$, nickel $(\mathrm{Ni})$ and zinc $(\mathrm{Zn})$. All the samples were filtered using $45 \mu \mathrm{m}$ membrane before analysis.

The major cations and all the trace elements were analysed in the geochemistry laboratory of the Department of Geology, University of Botswana using Inductively Coupled Plasma Mass Spectrometry or ICP-MS. The anions were analysed in the water quality laboratory of the Department of Water Affairs. For all the water samples alkalinity and hardness were determined using AquaChem software. 
The analytical precisions for the measurements of ions were determined by calculating the ionic balance error using the following formula.

$$
\text { Where, E.N }(\%)=\left[\frac{(\text { Sumcations }- \text { Sum anions })}{(\text { Sumcations }+ \text { Sum anions })}\right] * 100
$$

All the measurements are in milli equivalents per litre. It is found that the majority of the analyses were within the acceptable range.

Simple descriptive statistical method was utilized for the analyses of the water chemistry data. AquaChem and Suffer software's were also used for analyses the water chemistry data. AquaChem software is a fully integrated statistical package developed specifically for graphical and numerical analyses of aqueous geochemical data sets. Piper diagram and radial plots were prepared using this software for graphical presentation of the results and compare water quality data in the area. Suffer software was used to show contour map of distribution of elements in groundwater by Kriging method. Gibb's diagram was also used to see the relationship of water composition and aquifer lithological characteristics.

The suitability of the waters of the studied area for drinking purpose was evaluated with respect to the standard set by both the World Health Organisation [6] and the Botswana Bureau of Standard [7].

\section{Results and Discussions}

\subsection{Physico-Chemical Parameters}

The surface water is slightly alkaline to alkaline, fresh, and soft to very hard whereas the treated waste water is slightly alkaline, fresh and hard. Groundwater is slightly acidic to alkaline, fresh to saline and soft to very hard.

With the exception of the three samples in the groundwater, both groundwater and surface water of the study area show a high $\mathrm{pH}$ value as compared to the treated wastewater. High $\mathrm{pH}$ values could be associated with pollution emanated from the different activities of the society in the villages that are drained by the both surface water and groundwater of the catchment. A discharge of used water by the users that contains detergents and soap-based products can cause the water to become too basic.

This high pH can causes a bitter taste, water pipes and water-using appliances become encrusted with deposits, and it also depresses the effectiveness of the disinfection of chlorine, thereby causing the need for additional chlorine when $\mathrm{pH}$ is high.

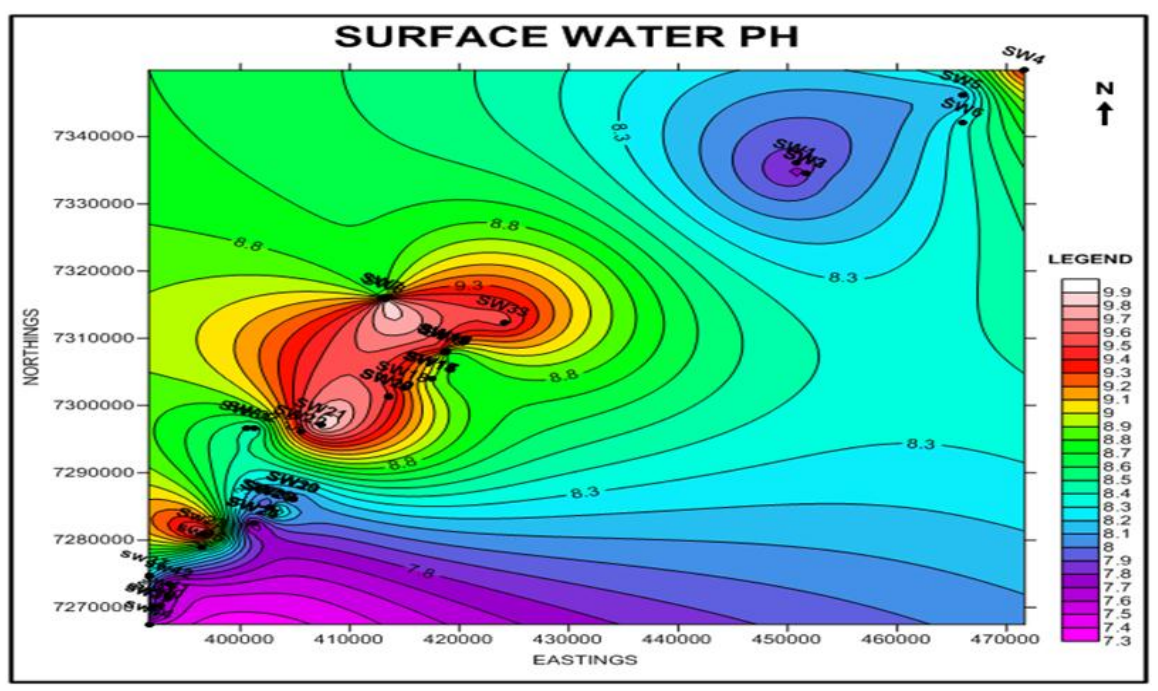

Figure-4. Surface water $\mathrm{pH}$

Source: Tshepo K., M.Sc. Thesis, University of Botswana, Gaborone, Botswana, 2017.

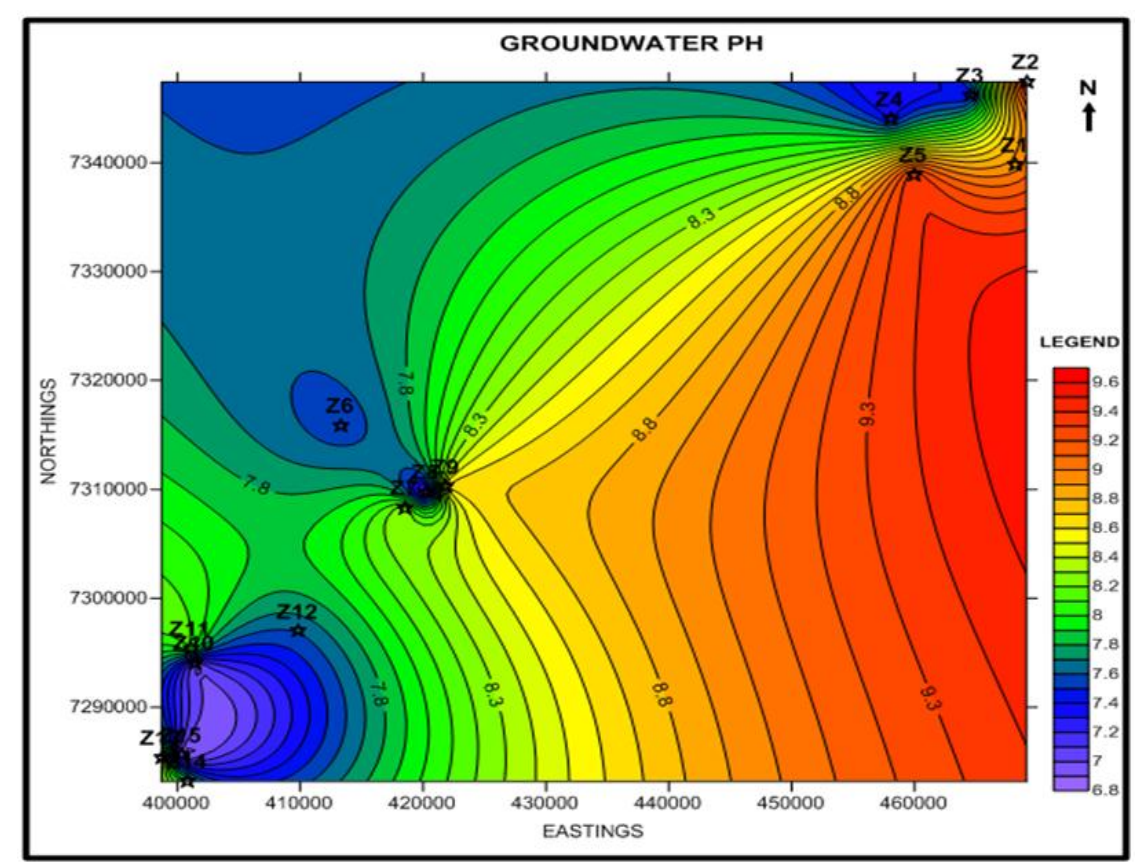

Figure-5. Groundwater $\mathrm{pH}$.

Source: Tshepo K., M.Sc. Thesis, University of Botswana, Gaborone, Botswana, 2017. 
Among the examined water samples, the highest value of both EC and TDS were measured in the groundwater of the catchment. 67 and 60 percent of the total groundwater samples have an EC of greater than $1000 \mu \mathrm{S} / \mathrm{cm}$ and a TDS greater than $1000 \mathrm{ppm}$, respectively. The minimum EC and TDS values are measured in boreholes $Z_{1}$ and $\mathrm{Z}$, which are located in the downstream side far from the river influences. The highest value of EC and TDS was measured in borehole $Z_{10}$, which is located in Mochudi village. In general boreholes close to the river bank of Notwane River (Z4, Z7, Z11, Z14 and Z15) and upstream side (Oodi and Mochudi villages) have high values of dissolved solids and electric conductivity values. These might be due to human activities associated with those major villages that have high number of population found in this part of the catchment.

This significant high value of EC and TDS of the groundwater as compared to the surface water and treated water suggesting that the groundwater is not only an infiltration of the local precipitation and treated water rather have an additional source (regional ) besides to that of surface water and the treated water. Uncontrolled sewage, pit latrines, fertilizer, pesticides application in farms and water rock interaction could also be contributed to the rise of these chemical parameters in the groundwater.

The table below shows the general water classification scale based on TDS [8].

Table-1. Groundwater classification

\begin{tabular}{l|l}
\hline Category Total dissolved solids $(\mathbf{m g} / \mathbf{L})$ \\
\hline Fresh water & $0-1000$ \\
\hline Brackish water & $1000-10$ 000 \\
\hline Saline water & 10 000-100 000 \\
\hline Brine water & More than 100 000 \\
\hline
\end{tabular}

Both the surface water and treated water alkalinity is a typical of fresh water alkalinity, which is in the range of 20 to $200 \mathrm{mg} / 1$ of $\mathrm{CaCO}_{3}$. Generally both waters are not poorly buffered, and are not also very susceptible to changes in $\mathrm{pH}$ from natural and human-caused sources.

With the exception of one sample, the alkalinity of the groundwater ranges from 43.31 to $474.06 \mathrm{mg} / \mathrm{lof}$ $\mathrm{CaCO}_{3}$ with mean value of $206.36 \mathrm{mg} / 1$ of $\mathrm{CaCO}_{3}$. This range of alkalinity is high as compared to the surface water and treated water. Groundwater sample Z7 has the highest alkalinity of $1208.53 \mathrm{mg} / \mathrm{l}$. The borehole from which sample Z7 was collected is located close to the river bank of Notwane River in the middle of study area (after the river has collected surface water from Bokaa, Pilane and Mochudi villages). The wastewater from the houses of the major villages or household wastes could be source of this high alkalinity in the groundwater. The wastewater from our houses contains carbonate and bicarbonate from the cleaning agents and food residue that we put down our drains. The cause to high alkalinity of the groundwater could also be the cause to this high hardness in the groundwater.

\subsection{Water Type}

Fifteen water types are recognized in the surface water of the studied area. Among them the dominants are Na$\mathrm{HCO}_{3}-\mathrm{Cl}, \mathrm{Na}-\mathrm{Mg}-\mathrm{HCO}_{3}-\mathrm{Cl}$ and $\mathrm{Ca}-\mathrm{Mg}-\mathrm{Na}-\mathrm{HCO} 3$ (Table 1). The treated wastewater is Na-Mg-HCO3-Cl type. Thirteen types of groundwater are identified in the study area. Among those water types the dominant ones are $\mathrm{Mg}-\mathrm{Ca}-\mathrm{Na}-\mathrm{Cl}$ and $\mathrm{Mg}-\mathrm{Cl}-\mathrm{HCO} 3$. In all the dominant water types of surface water and groundwater including treated wastewater the chemical analyses indicated the existence of $\mathrm{Cl}$ as major constituent in these water, and all these are found in the upstream side and middle of the catchment, suggesting a possible link with the anthropogenic activities associated with development activities in the upstream side of the catchment.

\subsection{Major Ions}

In all the waters, surface water, treated wastewater and groundwater based on the mean values of the chemical parameters, the cations were in the order of abundance as $\mathrm{Na}^{+}>\mathrm{Ca}^{2+}>\mathrm{Mg}^{2+}>\mathrm{K}^{+}>\mathrm{Li}^{+}$. Based on the mean values of the chemical parameters in the surface water the anions were in the order of abundance as $\mathrm{HCO}_{3}{ }^{-}>\mathrm{Cl}^{-}>\mathrm{SO}_{4}{ }^{2-}>$ $\mathrm{NO}_{3}{ }^{-}>\mathrm{PO}_{4}{ }^{3-}>\mathrm{F}^{-}>\mathrm{CO}_{3}{ }^{2-}$, in the treated water $\mathrm{HCO}_{3}{ }^{-}>\mathrm{Cl}^{-}>\mathrm{NO}_{3}{ }^{-}>\mathrm{SO}_{4}{ }^{2-}>\mathrm{PO}_{4}{ }^{3-}>\mathrm{F}^{-}>\mathrm{CO}_{3}{ }^{2-}$ while in the groundwater the anions reveal order of abundance as $\mathrm{Cl}^{-}>\mathrm{HCO}_{3}{ }^{-}>\mathrm{SO}_{4}{ }^{2-}>\mathrm{NO}_{3^{-}}>\mathrm{CO}_{3}{ }^{2-}>\mathrm{F}^{-}>\mathrm{PO}_{4}{ }^{3-}$.

The Figures 6 and 7 below show the piper diagram for surface water and treated wastewater and groundwater, respectively. Fig. 6 shows that in the anion triangle all samples are concentrated towards HCO3 indicating the dominancy of this species in the surface water and treated wastewater whereas Fig. 7 shows that dominant anion in the groundwater is $\mathrm{Cl}$. As for the cation in the surface water and treated wastewater, samples are clustered towards calcium and a combination of sodium and potassium, with a dominancy of $\mathrm{Na}+\mathrm{K}$ (Fig. 6). The diamond plot shows that the majority of the surface water samples and a treated wastewater sample lie below $40 \%$ of $\mathrm{Ca}$ and $\mathrm{Mg}$. As for the cation in the groundwater, samples are clustered towards a combination of sodium and potassium and magnesium end, with dominant number of samples toward the combination of sodium and potassium (Fig. 7). 
Table-2. Water types

\begin{tabular}{|c|c|c|c|c|c|}
\hline & Surface water & \multicolumn{2}{|c|}{ Groundwater } & \multicolumn{2}{|c|}{ Treated wastewater } \\
\hline $\begin{array}{l}\text { Sample } \\
\text { ID }\end{array}$ & water type & $\begin{array}{l}\text { Sample } \\
\text { ID }\end{array}$ & Water type & Sample ID & water type \\
\hline SW1 & $\mathrm{Na}-\mathrm{Mg}-\mathrm{CO} 3$ & $\mathrm{Z}_{1}$ & $\mathrm{Mg}-\mathrm{Na}-\mathrm{HCO} 3$ & SW36 & $\mathrm{Na}-\mathrm{Mg}-\mathrm{HCO} 3-\mathrm{Cl}$ \\
\hline SW2 & $\mathrm{Na}-\mathrm{HCO} 3-\mathrm{CO} 3$ & $\mathrm{Z2}$ & $\mathrm{Na}-\mathrm{Mg}-\mathrm{Cl}$ & & \\
\hline SW3 & $\mathrm{Na}-\mathrm{HCO} 3$ & Z3 & $\mathrm{Na}-\mathrm{Cl}-\mathrm{HCO} 3$ & & \\
\hline SW4 & $\mathrm{Mg}-\mathrm{Na}-\mathrm{Ca}-\mathrm{HCO} 3$ & $\mathrm{Z4}$ & $\mathrm{Mg}-\mathrm{Na}-\mathrm{Ca}-\mathrm{Cl}$ & & \\
\hline SW5 & $\mathrm{Ca}-\mathrm{Na}-\mathrm{HCO} 3$ & $\mathrm{Z5}$ & $\mathrm{Na}-\mathrm{Mg}-\mathrm{HCO} 3-\mathrm{Cl}$ & & \\
\hline SW6 & Na-HCO3 & Z6 & $\mathrm{Na}-\mathrm{Ca}-\mathrm{Mg}-\mathrm{SO} 4-\mathrm{Cl}-\mathrm{HCO} 3$ & & \\
\hline SW7 & $\mathrm{Mg}-\mathrm{Na}-\mathrm{Ca}-\mathrm{HCO} 3$ & $\mathrm{Z7}$ & $\mathrm{Mg}-\mathrm{HCO} 3$ & & \\
\hline SW8 & $\mathrm{Ca}-\mathrm{Mg}-\mathrm{Na}-\mathrm{HCO} 3$ & Z8 & $\mathrm{Ca}-\mathrm{Mg}-\mathrm{HCO} 3-\mathrm{NO} 3$ & & \\
\hline SW9 & $\mathrm{Mg}-\mathrm{Na}-\mathrm{Ca}-\mathrm{HCO} 3$ & Z9 & $\mathrm{Mg}-\mathrm{Na}-\mathrm{HCO} 3-\mathrm{Cl}$ & & \\
\hline SW 10 & $\mathrm{Na}-\mathrm{Mg}-\mathrm{HCO} 3-\mathrm{Cl}$ & $\mathrm{Z} 10$ & $\mathrm{Mg}-\mathrm{Ca}-\mathrm{Na}-\mathrm{Cl}$ & & \\
\hline SW 11 & $\mathrm{Na}-\mathrm{Mg}-\mathrm{Ca}-\mathrm{HCO} 3$ & $Z_{11}$ & $\mathrm{Mg}-\mathrm{Ca}-\mathrm{Na}-\mathrm{Cl}$ & & \\
\hline SW12 & $\mathrm{Mg}-\mathrm{Ca}-\mathrm{Na}-\mathrm{HCO} 3$ & Z12 & $\mathrm{Mg}-\mathrm{Cl}-\mathrm{HCO} 3$ & & \\
\hline SW 13 & $\mathrm{Na}-\mathrm{HCO} 3-\mathrm{Cl}$ & Z13 & $\mathrm{Na}-\mathrm{Mg}-\mathrm{Cl}-\mathrm{HCO} 3$ & & \\
\hline SW 14 & $\mathrm{Na}-\mathrm{Mg}-\mathrm{HCO} 3-\mathrm{Cl}$ & $Z_{14}$ & $\mathrm{Mg}-\mathrm{Cl}-\mathrm{HCO} 3$ & & \\
\hline SW 15 & $\mathrm{Na}-\mathrm{HCO} 3-\mathrm{Cl}$ & Z15 & $\mathrm{Mg}-\mathrm{Ca}-\mathrm{Cl}$ & & \\
\hline SW 16 & $\mathrm{Na}-\mathrm{Mg}-\mathrm{HCO} 3-\mathrm{Cl}$ & & & & \\
\hline SW 17 & $\mathrm{Na}-\mathrm{HCO} 3-\mathrm{Cl}$ & & & & \\
\hline SW 18 & $\mathrm{Na}-\mathrm{HCO} 3-\mathrm{Cl}$ & & & & \\
\hline SW 19 & $\mathrm{Na}-\mathrm{HCO} 3-\mathrm{Cl}$ & & & & \\
\hline SW2O & $\mathrm{Na}-\mathrm{HCO} 3-\mathrm{Cl}$ & & & & \\
\hline SW21 & $\mathrm{Na}-\mathrm{HCO} 3-\mathrm{Cl}$ & & & & \\
\hline SW22 & $\mathrm{Ca}-\mathrm{Mg}-\mathrm{Na}-\mathrm{HCO} 3$ & & & & \\
\hline SW23 & $\mathrm{Na}-\mathrm{HCO} 3-\mathrm{Cl}$ & & & & \\
\hline SW24 & $\mathrm{Na}-\mathrm{Mg}-\mathrm{Ca}-\mathrm{HCO} 3-\mathrm{Cl}$ & & & & \\
\hline SW25 & $\mathrm{Na}-\mathrm{Mg}-\mathrm{HCO} 3-\mathrm{Cl}$ & & & & \\
\hline SW26 & $\mathrm{Na}-\mathrm{HCO} 3-\mathrm{Cl}-\mathrm{SO} 4$ & & & & \\
\hline SW27 & $\mathrm{Na}-\mathrm{Mg}-\mathrm{HCO} 3-\mathrm{Cl}$ & & & & \\
\hline SW28 & $\mathrm{Na}-\mathrm{HCO} 3-\mathrm{Cl}$ & & & & \\
\hline SW29 & $\mathrm{Na}-\mathrm{Mg}-\mathrm{Ca}-\mathrm{HCO} 3-\mathrm{Cl}$ & & & & \\
\hline SW30 & $\mathrm{Na}-\mathrm{Mg}-\mathrm{HCO} 3-\mathrm{Cl}$ & & & & \\
\hline SW31 & $\mathrm{Na}-\mathrm{Mg}-\mathrm{Ca}-\mathrm{HCO} 3$ & & & & \\
\hline SW32 & $\mathrm{Ca}-\mathrm{Mg}-\mathrm{HCO} 3$ & & & & \\
\hline SW33 & $\mathrm{Mg}-\mathrm{Ca}-\mathrm{HCO} 3$ & & & & \\
\hline SW34 & $\mathrm{Mg}-\mathrm{Ca}-\mathrm{Na}-\mathrm{HCO} 3$ & & & & \\
\hline SW35 & $\mathrm{Ca}-\mathrm{Mg}-\mathrm{HCO} 3-\mathrm{Cl}$ & & & & \\
\hline SW37 & $\mathrm{Ca}-\mathrm{Mg}-\mathrm{HCO} 3$ & & & & \\
\hline SW38 & $\mathrm{Ca}-\mathrm{Mg}-\mathrm{HCO} 3-\mathrm{Cl}$ & & & & \\
\hline SW39 & Na-HCO3-Cl & & & & \\
\hline SW40 & Ca-Mg-Na-HCO3 & & & & \\
\hline SW41 & $\mathrm{Ca}-\mathrm{Mg}-\mathrm{Na}-\mathrm{HCO} 3$ & & & & \\
\hline SW42 & $\mathrm{Ca}-\mathrm{Mg}-\mathrm{HCO} 3$ & & & & \\
\hline
\end{tabular}

Source: Tshepo K., M.Sc. Thesis, University of Botswana, Gaborone, Botswana, 2017.

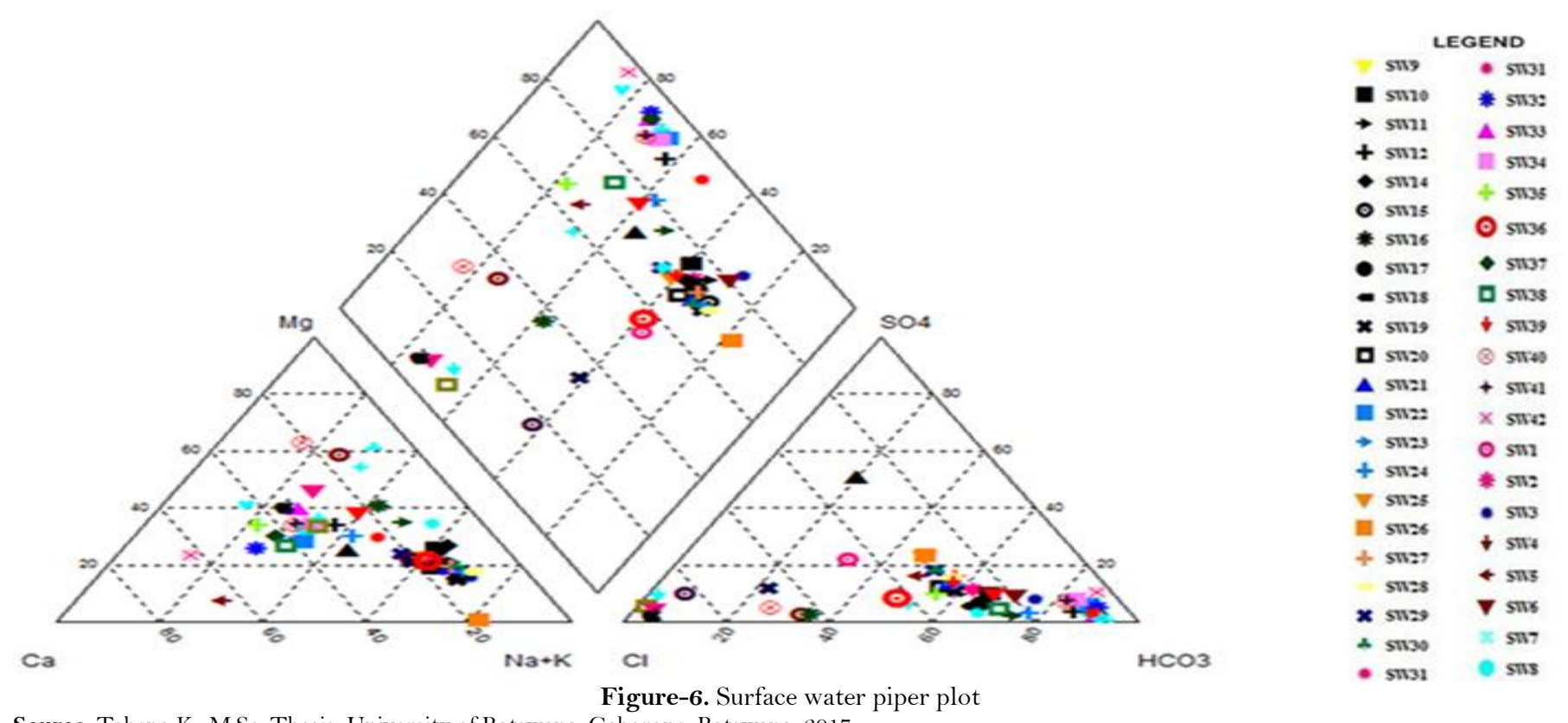

Source: Tshepo K., M.Sc. Thesis, University of Botswana, Gaborone, Botswana, 2017. 


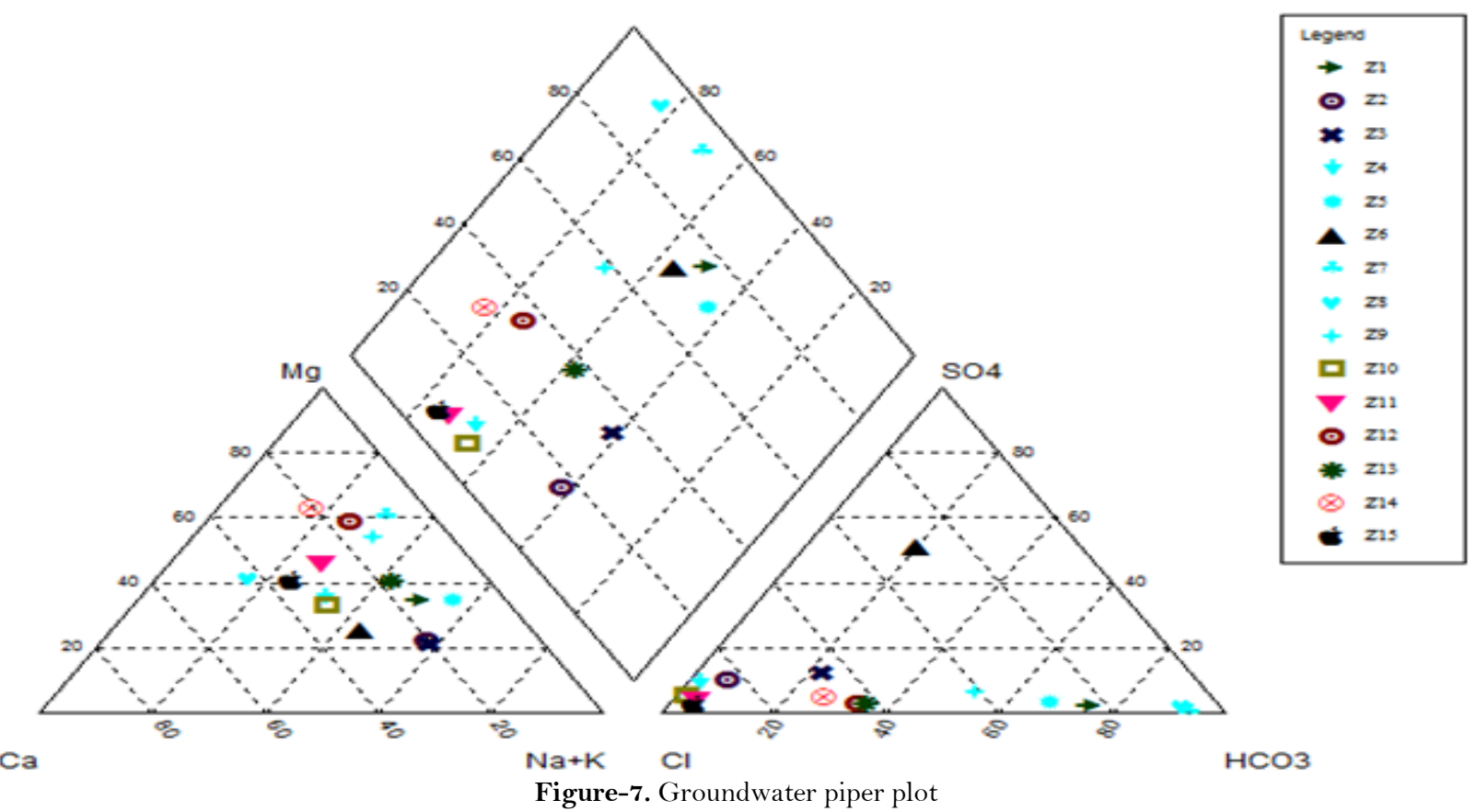

Source: Tshepo K., M.Sc. Thesis, University of Botswana, Gaborone, Botswana, 2017.

In the treated wastewater, the concentration of the major cations with the exception of Li have a concentration greater than the concentration in the surface water, whereas in the groundwater the concentrations of all the major cations are greater than the concentrations of the major cations in both the surface and treated waste water.

In the treated wastewater, the concentration of the analyzed major anions with the exception of fluorine and carbonate, have a concentrations greater than surface water whereas in the groundwater, the concentration of all the analyzed major anions are greater than the concentrations both the surface and treated wastewater, with the exception of carbonate and phosphate.

In the groundwater, the measured concentration of $\mathrm{Cl}^{-}(1322.5 \mathrm{mg} / \mathrm{l})$ and $\mathrm{NO}_{3^{-}}(60.67 \mathrm{mg} / \mathrm{l})$ is much greater than the measured concentrations of these ions both in the surface and treated wastewater whereas the measured concentration of $\mathrm{PO}_{4}{ }^{3-}$ in the groundwater is significantly less than the measured concentration of $\mathrm{PO}_{4}{ }^{3-}$ in both surface water and treated wastewater. The highest measured concentration of $\mathrm{PO}_{4^{3-}}{ }^{3-}(9.53 \mathrm{mg} / \mathrm{l})$ is in the treated wastewater. Uncontrolled human wastes or sewage are the possible sources of $\mathrm{Cl}^{-}$and $\mathrm{NO}_{3}{ }^{-}$ions in the groundwater. The presence of high concentration of phosphate ion in the treated wastewater and absence of more or less corresponding concentration in both the surface water and groundwater implies that the treated water is not the source for pollution to both surface and groundwater in the catchment.

In the analysed groundwater of the catchment the concentrations of all the analyzed major cations and anions (with the exception of carbonate and phosphate) are greater than the concentrations of the analyzed major cations and anions in both the surface water and treated waste water suggesting that the overall chemistry of the groundwater is not only controlled by the chemistry of the original precipitation and the chemistry of the treated wastewater rather by the water-rock interaction processes while the groundwater transmitted and stored in the different rock formations of the catchment .

Supporting this idea the Gibbs diagram below (Figure 8) shows the controlling mechanism of groundwater quality is rock weathering dominance. Fourteen samples out of fifteen are within the rock weathering dominance, while one sample collected in borehole $\mathrm{Z} 7$ indicated evaporation dominance.

In addition to that Figure 9 (dominant cation vs dominant anions) also shows that silicate weathering is the major process that control the rock-water interaction processes in the catchment. Most of the boreholes are drilled in the igneous rocks formation found in the upstream side of the catchment.

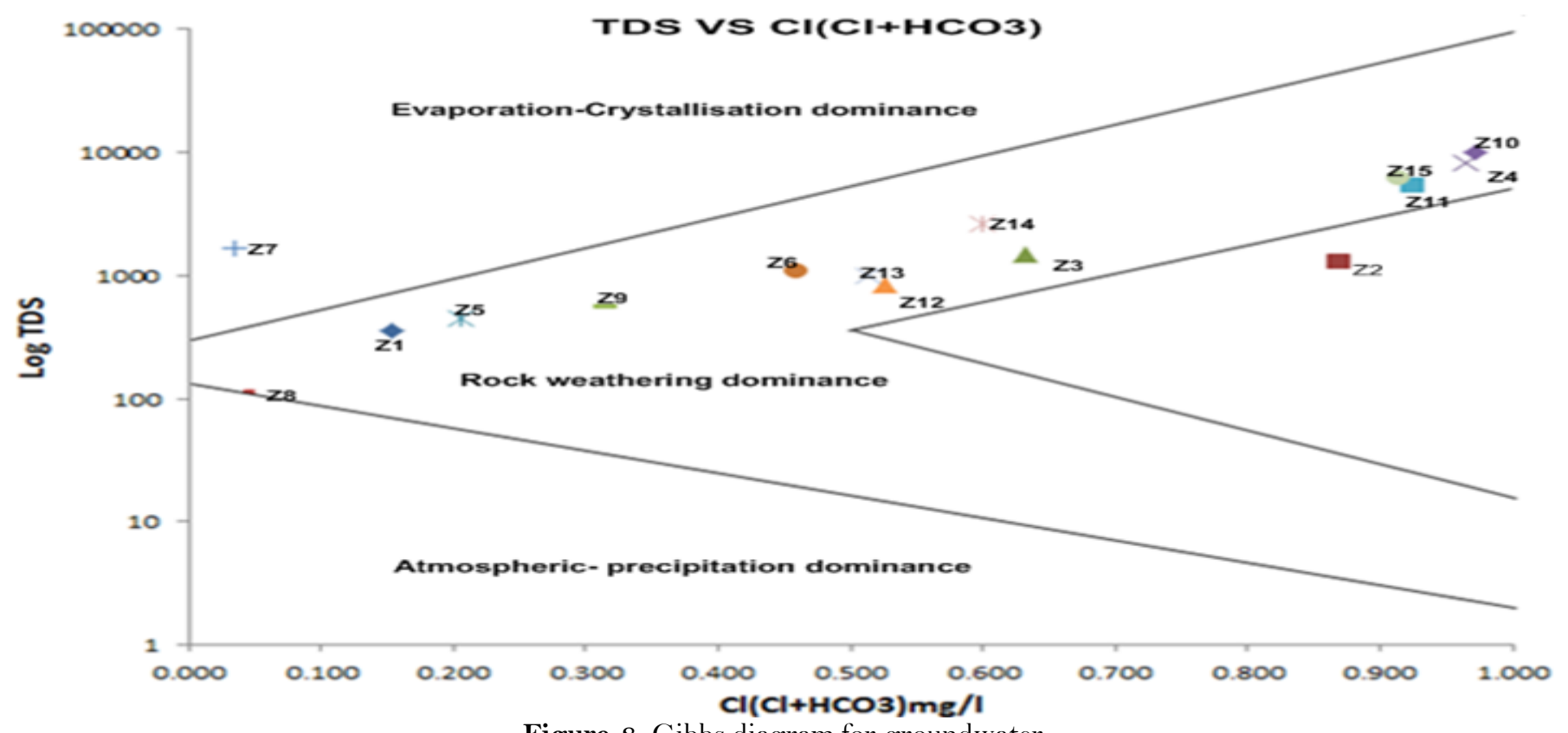

Source: Tshepo K., M.Sc. Thesis, University of Botswana, Gaborone, Botswana, 2017. 


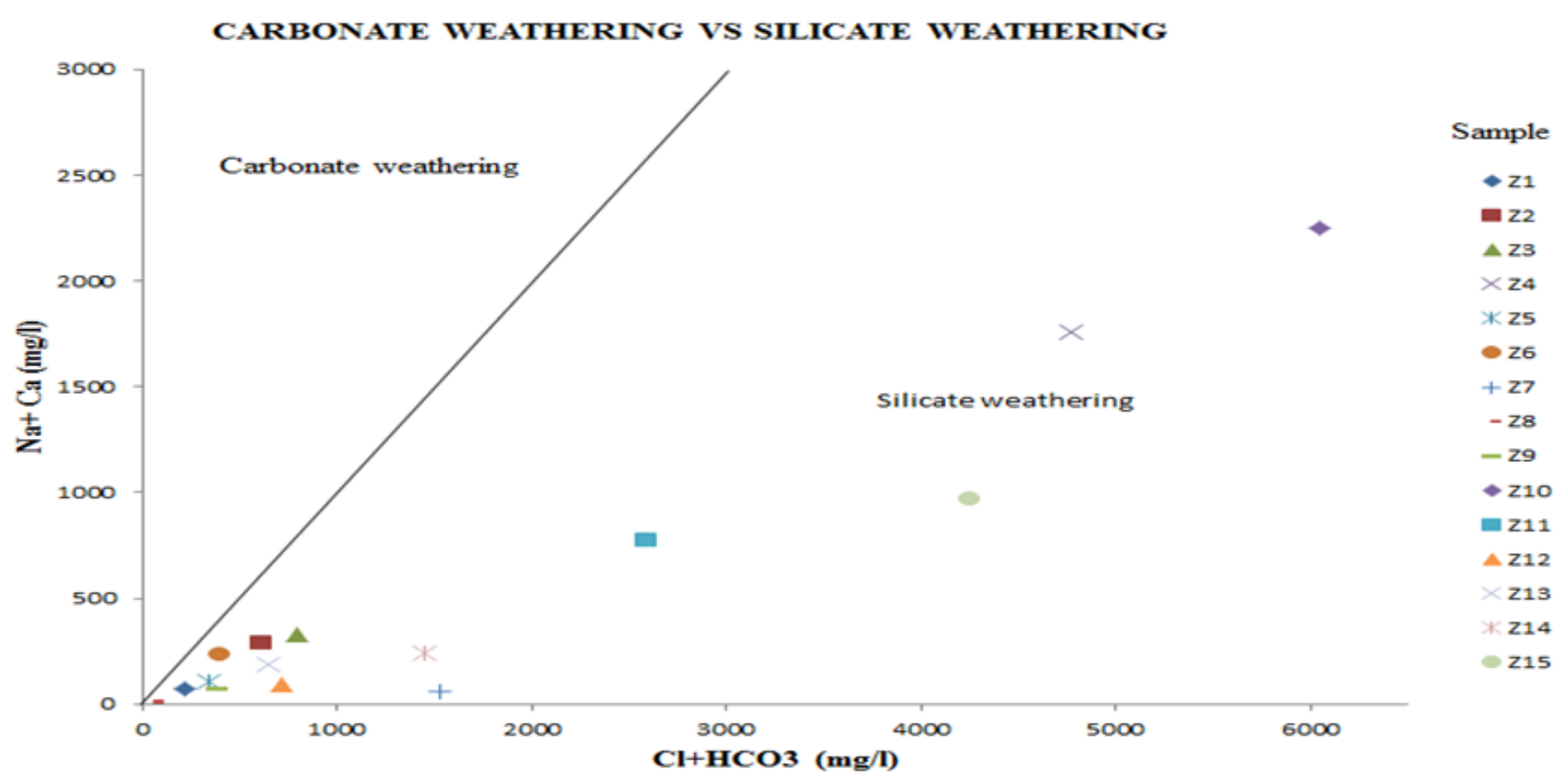

Figure-9. Groundwater carbonates weathering vs silicate weathering.

Source: Tshepo K., M.Sc. Thesis, University of Botswana, Gaborone, Botswana, 2017.

\subsection{Trace Elements}

All the analyzed trace elements in the treated wastewater, with the exception of cadmium and cobalt, have a concentration less than the concentration in the groundwater of the catchment. In the treated wastewater, with the exception of $\mathrm{Ni}$ and $\mathrm{Zn}$, all the remaining analyzed trace elements have a concentration less than concentration in the surface water. Therefore in the treated wastewater the concentration of zinc is insignificant to be a pollutant. However, the concentration of $\mathrm{Ni}$ is not avoidable to be a pollutant toward the surface water and groundwater of the catchment: though it is not the only source. The different mineralogical compositions of the rocks of the studied area have also their own contribution.

\section{Conclusions}

In all the water, surface water, treated wastewater and groundwater, the dominant cations and anions are sodium, calcium, bicarbonate and chlorine. In all the waters the dominant cation is $\mathrm{Na}^{+}$. In all the waters, surface water, treated wastewater and groundwater, based on the mean values of the chemical parameters, the cations were in the order of abundance as $\mathrm{Na}^{+}>\mathrm{Ca}^{2+}>\mathrm{Mg}^{2+}>\mathrm{K}^{+}>\mathrm{Li}^{+}$. In both the surface water and treated wastewater the dominant anion is $\mathrm{HCO}^{-}$whereas in groundwater is $\mathrm{Cl}^{-}$. Based on the mean values of the chemical parameters, in the surface water the anions were in the order of abundance as $\mathrm{HCO}_{3}{ }^{-}>\mathrm{Cl}^{-}>\mathrm{SO}_{4}{ }^{2-}>\mathrm{NO}_{3}{ }^{-}>\mathrm{PO}_{4}{ }^{3-}>\mathrm{F}^{-}>\mathrm{CO}_{3}{ }^{2-}$, in the treated water $\mathrm{HCO}_{3}{ }^{-}>\mathrm{Cl}^{-}>\mathrm{NO}_{3}{ }^{-}>\mathrm{SO}_{4}{ }^{2-}>\mathrm{PO}_{4}{ }^{3-}>\mathrm{F}^{-}>\mathrm{CO}_{3}{ }^{2-}$ while in the groundwater the anions reveal order of abundance as $\mathrm{Cl}^{-}>\mathrm{HCO}_{3}{ }^{-}>\mathrm{SO}_{4}{ }^{2-}>\mathrm{NO}_{3}{ }^{-}>\mathrm{CO}_{3}{ }^{2-}>\mathrm{F}^{-}>\mathrm{PO}_{4}{ }^{3-}$.

Among the analyzed trace elements, the dominant in all the water, surface water, treated wastewater and groundwater is nickel. Based on the mean values of the chemical parameters, the order of abundance of trace elements in the surface water was $\mathrm{Ni}>\mathrm{Fe}>\mathrm{Pb}>\mathrm{Ba}>\mathrm{Zn}>\mathrm{Mn}>\mathrm{Cd}>\mathrm{As}>\mathrm{Co}>\mathrm{Cr}>\mathrm{Cu}$, in the treated wastewater $\mathrm{Ni}>\mathrm{Ba}>\mathrm{Zn}>\mathrm{Pb}>\mathrm{Fe}>\mathrm{Cd}>\mathrm{Mn}>\mathrm{As}>\mathrm{Co}>\mathrm{Cr}$ and $\mathrm{Cu}$ having equal concentration $(\mathrm{O} \mathrm{mg} / \mathrm{l})$ while in the groundwater the analyzed trace element reveal order of abundance as $\mathrm{Ni}>\mathrm{Pb}>\mathrm{Ba}>\mathrm{Mn}>\mathrm{Zn}>\mathrm{Fe}>\mathrm{Cd}>$ As $>\mathrm{Cu}>\mathrm{Co}>\mathrm{Cr}$.

The overall chemical analyses of the water chemistry revealed that the hydrochemistry of the groundwater in the study area is not only controlled by the chemistry of the original precipitation, chemistry of surface water and chemistry of treated wastewater but also dominantly by the water-rock interaction processes while the groundwater transmitted and stored in the different rock formations of the catchment and anthropogenic activities in the area.

The analysed cations for surface water and treated wastewater satisfy the standard of both WHO and Botswana Bureau of Standards whereas in the groundwater the cations are highly above the recommended limits of the standards set by both WHO and Botswana Bureau of Standards with the exception of potassium. The tested anions for surface water and treated wastewater satisfy the standard of both WHO and Botswana Bureau of Standards whereas in the groundwater the concentration of $\mathrm{Cl}$ and $\mathrm{NO}_{3}$ were above the standards set by both WHO andBotswana Bureau of Standards. In the analysed trace elements for all the waters, almost all samples met the trace element standards set by both WHO andBotswana Bureau of Standards with the exception of nickel and lead in surface water, treated wastewater and groundwater.

Generally, on the basis of the overall chemical analyses of the water chemistry, the study revealed that treated wastewater quality does not have any significant harm to both surface and groundwater quality; therefore it can be used as a source of recharge to the aquifers in the catchment.

\section{References}

[1] B. F. Alemaw, E. M. Shemang, and T. R. Chaoka, "Assessment of groundwater pollution vulnerability and modelling of the Kanye Wellfield in SE Botswana-a GIS approach," Physics and Chemistry of the Earth, Parts A/B/C, vol. 29, pp. 1125-1128, 2004. View at Google Scholar | View at Publisher Botswana Central 
[4] V. Emongor and G. Ramolemana, "Treated sewage effluent (Water) potential to be used for horticultural production in Botswana," Physics and Chemistry of the Earth, Parts A/B/C, vol. 29, pp. 1101-1 108, 2004. View at Google Scholar | View at Publisher

R. A. Freeze and J. A. Cherry, Groundwater (1979). Englewood Cliffs: Printice-Hall Inc, 1979.

Ministry of Minerals Energy Water Resources, Botswana water accounting report 2015. Gaborone: Botswana Government, 2015.

B. P. Parida and D. B. Moalafhi, "Regional rainfall frequency analysis for Botswana using L-moments and radial basis function network," Physics and Chemistry of the Earth, Parts A/B/C, vol. 33, pp. 614-620, 2008. View at Google Scholar | View at Publisher

World Health Organization, Guidelines for drinking-water quality. New York: IWA Publishing, 2004. 